\title{
Presence of ERBB2 Overexpressing Disseminated Tumor Cells
}

National Cancer Institute

\section{Source}

National Cancer Institute. Presence of ERBB2 Overexpressing Disseminated Tumor

Cells. NCI Thesaurus. Code C153406.

An indication that single tumor cells or small clusters of tumor cells that are overexpressing ERBB2 are present in a tissue sample. 